\title{
MITIGACIÓN DEL ESTRÉS CALÓRICO DURANTE EL PREPARTO EN VACAS LECHERAS
}

\author{
Toffoli, G.D.1; LeVA, P.E. ${ }^{1}$; SosA, J.L. ${ }^{2}$; GHIANO, J.E.J.3;

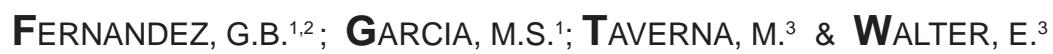

\begin{abstract}
RESUMEN
Se utilizaron 30 vacas en preparto que se alojaron en un corral seco con acceso a sombra artificial durante el verano. Las vacas fueron distribuidas en dos grupos: sin refrescado (TS) y con refrescado (TR) en el sector comedero. El peso corporal y la condición corporal fueron evaluadas al inicio y a los 25 días. La frecuencia respiratoria se realizó dos veces por semana en cuatro momentos del día. El registro de comportamiento dos veces a la semana. Los datos de analizaron con t Student y $\chi^{2}$. El peso y condición corporal no presentaron diferencia significativa. Se observó un efecto del tratamiento en el día y horario para la frecuencia respiratoria $(\mathrm{p}<0,0001)$. La conducta de parado a la sombra fue al que dedicaron mayor tiempo en ambos tratamientos $27 \%$ en TS y $29 \%$ en TR. No hubo diferencias en la producción lechera entre TS y TR: 31,4 l/v/d y 30,6 1/v/d respectivamente.
\end{abstract}

Palabras clave: conducta, frecuencia respiratoria, producción lechera.

\begin{abstract}
Mitigation of prenatal caloric stress in dairy cows.

Thirty cows in prepartum who stayed in a dry pen with access to artificial shadows were used. The cows were divided into two groups: unrefrigerated (TS) and refrigeration (TR) in the feeder sector. At the start of the trial at 25 days it was evaluated weight and body condition. Twice a week and times of day four respiratory rate was measured. Twice a week the behavior was recorded the data analyzed with T Student and chi square. Weight and body condition showed no significant difference .It observed a treatment effect on the day and time for the respiratory rate $(p<0.0001)$. The behavior of standing in the shadow was the highest in TS $27 \%$ and $29 \%$ in TR. There were no statistical differences in milk production between treatments in the sun and chilled which was 31,4 $1 / \mathrm{v} / \mathrm{d}$ and $30,61 / \mathrm{v} / \mathrm{d}$. respectively.
\end{abstract}

Key words: behavior, respiratory rate and milk production.

1.- Facultad de Ciencias Agrarias (UNL). Kreder 2805. (3080HOF) Esperanza, provincia de Santa Fe. Email: guilletoffoli@hotmail.com

2.- Facultad de Ciencias Veterinarias (UNL). Kreder 2805. (3080HOF) Esperanza, provincia de Santa Fe.

2.- Técnicos de la Estación Experimetnal INTA Rafaela. (2300) Rafaela, provincia de Santa Fe.

Manuscrito recibido el 4 de abril de 2016 y aceptado para su publicación el 11 de octubre de 2016. 